\title{
Thermocladium modestius gen. nov., sp. nov., a new genus of rod-shaped, extremely thermophilic crenarchaeote
}

\author{
Takashi Itoh, Ken-ichiro Suzuki and Takashi Nakase
}

Japan Collection of Microorganisms, The Institute of Physical and Chemical Research (RIKEN), Wako-shi, Saitama 351-0198, Japan

\author{
Author for correspondence: Takashi Itoh. Tel: +81 48467 9560. Fax: +81 484624617 . \\ e-mail: ito@ulmus.riken.go.jp
}

\begin{abstract}
Three strains of novel, extremely thermophilic, rod-shaped crenarchaeotes were isolated from acidic hot spring areas in Japan. Cells of the three strains were straight or slightly curved rods and occasionally branched out singly or extensively, or had spherical bodies protruding at the ends of the cells. They were heterotrophs that grew anaerobically or microaerobically. The presence of $\mathrm{CO}_{2}$ in the gas phase, archaeal cell-extracts and a vitamin mixture stimulated growth of the strains. Growth occurred at $45-82{ }^{\circ} \mathrm{C}$ and $\mathrm{pH} 2 \cdot 6-5 \cdot 9$ and was optimal around $75{ }^{\circ} \mathrm{C}$ and $\mathrm{pH} 4 \cdot 0$. The strains utilized glycogen, starch, gelatin and various proteinaceous complex compounds as carbon sources. They required sulfur, thiosulfate or L-cystine as possible electron acceptors. The lipids mainly consisted of various cyclic glycerol-bisdiphytanyl-glycerol tetraethers. The G+C contents of the genomic DNAs were $52 \mathrm{~mol} \%$. Comparison of the 165 rDNA sequences indicated that they belonged to a separate lineage in the family Thermoproteaceae. The three strains were included in a single species due to high levels of DNA-DNA hybridization values. Based upon these results, the new isolates were assigned to a new genus and species in the family Thermoproteaceae, Thermocladium modestius gen. nov., sp. nov. The type strain is Thermocladium modestius IC-125' ( = JCM 10088').
\end{abstract}

Keywords: Thermocladium modestius, extreme thermophile, crenarchaeotes, Thermoproteaceae

\section{INTRODUCTION}

Accumulation of $16 \mathrm{~S} \mathrm{rRNA} / \mathrm{rDNA}$ sequence data has revealed that the domain Archaea is composed of two major branches, the kingdoms Euryarchaeota (euryarchaeotes) and Crenarchaeota (crenarchaeotes) (Woese et al., 1990). Currently isolated species of the crenarchaeotes are all extreme thermophiles or hyperthermophiles (Stetter, 1996), although crenarchaeal signatures have been discovered in nucleic acids from mesophilic or psychrophilic habitats (Hershberger et al., 1996). The thermophilic crenarchaeotes have been mainly isolated from geothermally heated terrestrial or submarine environments (Huber \& Stetter, 1992; Segerer \& Stetter, 1992). Such biotopes allow diverse microbial communities, including a variety of cren-

The DDBJ accession number for the 165 rDNA sequence of strain IC-125 reported in this paper is AB005296. archaeote genera and species to occur, as exemplified by a hot spring sample collected from Yellowstone National Park, USA (Barns et al., 1994).

In this paper, the isolation and the taxonomic and phylogenetic characteristics of three rod-shaped crenarchaeote strains thriving around $75^{\circ} \mathrm{C}$ and $\mathrm{pH} 4.0$ are described; a new genus and species in the family Thermoproteaceae is proposed for these three strains, Thermocladium modestius gen. nov., sp. nov.

\section{METHODS}

Isolation procedure. Samples of hot spring water, muds and soils were collected from several sites associated with volcanic activity in Japan. The samples were transported in sterile plastic tubes at ambient temperature. The basal salts medium for Sulfolobus (Brock et al., 1972), supplemented with $0.2 \mathrm{~g}$ yeast extract $1^{-1}$ (Difco), $1.0 \mathrm{mg}$ resazurin $\mathrm{l}^{-1}, 5.0 \mathrm{~g}$ sulfur powder $\mathrm{l}^{-1}$ and adjusted to $\mathrm{pH} 5 \cdot 0$ at room tem- 
perature, was used as an enrichment medium. The basal salts medium and yeast extract [a $10.0 \%(\mathrm{w} / \mathrm{v})$ solution] were separately autoclaved at $121^{\circ} \mathrm{C}$ for $15 \mathrm{~min}$. Sulfur was sterilized by autoclaving at $105^{\circ} \mathrm{C}$ for $1 \mathrm{~h}$. Ten millilitres of the medium, contained in a serum bottle, was flushed with a $\mathrm{H}_{2} / \mathrm{CO}_{2}$ gas mixture $(4: 1, \mathrm{v} / \mathrm{v})$ and was reduced with sterile $\mathrm{Na}_{2} \mathrm{~S} .9 \mathrm{H}_{2} \mathrm{O}$ solution (final concn $0.5 \mathrm{~g} \mathrm{l}^{-1}$ ). After readjusting the pH to 5.0 with $0.5 \mathrm{M} \mathrm{H}_{2} \mathrm{SO}_{4}$, the bottle was sealed with a butyl rubber stopper. After inoculation, the culture was pressured to $100 \mathrm{kPa}$ with $\mathrm{H}_{2} / \mathrm{CO}_{2}(4: 1, \mathrm{v} / \mathrm{v})$ and incubated at $70^{\circ} \mathrm{C}$ for 1 week.

Culture conditions. TCD medium was developed to compare the effect of medium composition on growth. It consisted of 1.01 basal salts medium of the Sulfolobus medium (Brock et al., 1972), $0.5 \mathrm{~g}$ yeast extract, $10 \mathrm{ml}$ archaeal cell-extract solution, $1.0 \mathrm{mg}$ resazurin and $10.0 \mathrm{~g}$ sulfur powder. The $\mathrm{pH}$ was adjusted to $4.0-4.5$ at room temperature. The gas phase was either $\mathrm{N}_{2}$ or a $\mathrm{H}_{2} / \mathrm{CO}_{2}(4: 1, \mathrm{v} / \mathrm{v} ; 100 \mathrm{kPa})$ gas mixture; the medium was reduced by the addition of $0.5 \mathrm{~g} \mathrm{l}^{-1}$ (final concn) $\mathrm{Na}_{2} \mathrm{~S} .9 \mathrm{H}_{2} \mathrm{O}$ just before use. The archaeal cell-extract solution was prepared by the modified method of Fiala $e t$ al. (1986). Namely, 1 g packed cells of Sulfolobus acidocaldarius, Methanosarcina barkeri, Halobacterium salinarum or Thermoplasma acidophilum was suspended in $100 \mathrm{ml}$ distilled water and disrupted by an ultrasonic oscillator (Sonifier model 250 ; Branson) for $30-45 \mathrm{~min}$ (50\% duty cycle; i.e. $0.5 \mathrm{~s}$ ultrasonic exposure and $0.5 \mathrm{~s}$ non-exposure per cycle) on ice. The homogenate was centrifuged at $12000 \mathrm{~g}$ for $10 \mathrm{~min}$ and the supernatant was filter-sterilized (pore size $0.2 \mu \mathrm{m}$; Minisart, Sartorius). This solution ( $1 \%, \mathrm{w} / \mathrm{v})$ was stored at $4{ }^{\circ} \mathrm{C}$ until use. To obtain sufficient biomass for isolation of DNAs and lipids, yeast extract concentration in the medium was increased to $1 \cdot 0 \mathrm{~g} \mathrm{1}^{-1}$.

Morphology. The cells were observed directly under a phasecontrast light-microscope (Optiphot-2; Nikon), or shadowed with platinum/palladium and examined with a transmission electron microscope (model H-300; Hitachi).

Growth characteristics. Unless otherwise indicated, isolates were cultivated in TCD medium under an $\mathrm{N}_{2}$ atmosphere at $75^{\circ} \mathrm{C}$. The cell-extract solution was prepared from Sulfolobus acidocaldarius JCM 8929 ${ }^{\mathrm{T}}$. To test for aerobic and microaerobic growth, $\mathrm{Na}_{2} \mathrm{~S} .9 \mathrm{H}_{2} \mathrm{O}$ was omitted from the TCD medium and the gas phase was either air or $\mathrm{N}_{2}$ containing $5 \%(\mathrm{v} / \mathrm{v})$ air, respectively. Trisodium citrate (10 mM, pH $2 \cdot 0-5 \cdot 5)$ or $\mathrm{MES}(10 \mathrm{mM}$, pH 5.0-7.0) was added to the TCD medium to examine the effect of $\mathrm{pH}$. The $\mathrm{pH}$ of the medium was adjusted at room temperature by the addition of $\mathrm{H}_{2} \mathrm{SO}_{4}$ or $\mathrm{NaOH}$. Sulfide production was determined qualitatively as described by Huber et al. (1986).

Protein assay. Due to the highly variable size of cells, it was difficult to estimate the total growth yield of the culture by counting cell numbers. Therefore, cellular protein content was determined as an estimate of the growth yield. The cultures were centrifuged at $12000 \mathrm{~g}$ for $10 \mathrm{~min}$ and the pelleted cells were suspended in $5 \%(\mathrm{w} / \mathrm{v})$ trichloroacetic acid solution followed by incubation at $90^{\circ} \mathrm{C}$ for $15 \mathrm{~min}$. The suspension was centrifuged again and the precipitated cellular protein was solubilized in $0.5 \mathrm{M} \mathrm{NaOH}$ solution. The protein concentration was measured by the $\mathrm{BCA}$ (bicinchoninic acid) protein assay kit (Pierce) as described by the supplier's protocol. BSA was used as a standard protein.

Utilization of carbon sources. Each of the test compounds was added to the TCD medium prepared without yeast extract. D-Arabinose, D-fructose, D-galactose, D-glucose, lactose, maltose, D-mannose, D-ribose, sucrose, D-xylose, glycogen and soluble starch were added at final concentrations of $0.5 \%(\mathrm{w} / \mathrm{v})$. Acetate, butyrate, citrate, formate, fumarate, lactate, L-malate, propionate, pyruvate, succinate, L-alanine, L-arginine, L-asparagine, L-aspartic acid, L-cysteine, L-glutamic acid, L-glutamine, glycine, L-histidine, Lisoleucine, L-leucine, L-lysine, L-methionine, L-phenylalanine, L-proline, L-serine, L-threonine, L-tryptophan, Ltyrosine, L-valine, methanol, ethanol, formamide, monomethylamine, trimethylamine and gelatin (Difco) were added at $0 \cdot 2 \%$. Beef extract, casamino acids, malt extract, peptone, tryptone and yeast extract (all from Difco) were added at $0.05 \%$.

Possible electron acceptors. The following basal medium was designed to test possible electron acceptors (made up in 1.01 distilled water): $0.53 \mathrm{~g} \mathrm{NH}_{4} \mathrm{Cl} ; 0.28 \mathrm{~g} \mathrm{KH}_{2} \mathrm{PO}_{4} ; 0.2 \mathrm{~g}$ $\mathrm{MgCl}_{2} \cdot 6 \mathrm{H}_{2} \mathrm{O} ; 0.07 \mathrm{~g} \mathrm{CaCl}_{2} .2 \mathrm{H}_{2} \mathrm{O} ; 0.5$ g yeast extract $; 10 \mathrm{ml}$ archaeal cell-extract solution; $9.0 \mathrm{ml}$ trace mineral solution of Zeikus (1977); and 1.0 mg resazurin. The medium was adjusted to $\mathrm{pH} 4.0$ at room temperature with $\mathrm{HCl}$. Sulfur, sodium thiosulfate, sodium sulfate, sodium sulfite, L-cystine, oxidized glutathione, fumarate, L-malate, sodium nitrate or $\mathrm{FeCl}_{3}$ was added to the basal medium at a final concentration of $20 \mathrm{mM}$ or $6.4 \mathrm{~g} \mathrm{l}^{-1}$ (sulfur only). Each of the media was reduced by the addition of titanium (III) citrate (final concn $1.3 \mathrm{mM}$ ) as described by Zehnder \& Wuhrmann (1976).

Sensitivity to antibiotics. Ampicillin, chloramphenicol, erythromycin, kanamycin, oleandomycin, rifampicin or vancomycin was added to the TCD medium at a concentration of $100 \mu \mathrm{g} \mathrm{ml}^{-1}$. Degradation of the antibiotics during the cultivation was estimated using Bacillus sphaericus JCM 2502 as a test organism.

Lipid analysis. Whole-cell acid methanolysis was performed as described by Ross et al. (1985). The degraded products were analysed by thin-layer chromatography on Kieselgel 60 (Merck). Diether- and tetraether core lipids were detected on the thin-layer chromatogram developed with hexane/diether $(80: 20, \mathrm{v} / \mathrm{v})$ (Ross et al., 1985) and hexane/ethyl acetate $(70: 30, \mathrm{v} / \mathrm{v})$ (Trincon et al., 1988), respectively.

Isolation of DNA, G+C content analysis and DNA-DNA hybridization. Packed cells were suspended in standard saline/citrate solution and lysed with $1 \%(\mathrm{w} / \mathrm{v}) \mathrm{SDS}$ at $60{ }^{\circ} \mathrm{C}$ for $5 \mathrm{~min}$. Genomic DNAs were isolated from the lysates and purified; their $\mathrm{G}+\mathrm{C}$ content was determined as described by Tamaoka (1994). DNA-DNA hybridization studies were undertaken according to the fluorescent method of Ezaki et al. (1989). Thermoproteus tenax JCM $9277^{\mathrm{T}}$ $\left(=\right.$ DSM $\left.2078^{\mathrm{T}}\right)$ was used as a reference strain.

165 rDNA analysis. Nearly complete $16 \mathrm{~S}$ rDNA of the strain IC- $125^{\mathrm{T}}$ was amplified by PCR, cloned into pDIRECT vectors, and transformed into Escherichia coli DH5 $\alpha$ competent cells using the PCR-Direct Cloning System (Clontech). The PCR primers, which include PCR-Direct sequences (underlined) at the $5^{\prime}$ ends, were designed as follows: forward primer, 5' CTCGCTCGCCCACCGGTTGATCCTGCC (positions 9-23 in E. coli numbering system); reverse primer, 5' CTGGTTCGGCCCAAAGGAGGTGATCCARCCG (positions 1540-1525). The ALFred DNA sequencer and the AutoCycle Sequencing kit of Pharmacia Biotech were used for sequencing. For sequencing both strands of DNA, the M13-universal primer, the M13-reverse primer and the following primers were used: $5^{\prime}$ GGCACTGAGACAAGGGCC (positions 318-335), 5' GGATTTCRCCCCTAC (positions 699-685), 5' GGGTAGGGGCGAAAT- 
CC (positions 683-699), 5' GAGAGGAGGTGCATGGCCG (positions 1043-1061) and 5' GGYGGGGGTCTCGCTCG (positions 1119-1102). The sequence obtained was aligned with those of some crenarchaeotes and Thermococcus celer as the root organism with the CLUSTAL w program (Thompson et al., 1994). Nucleotide substitution rates were calculated after gaps and unknown bases were eliminated. The phylogenetic tree was constructed according to the neighbour-joining method (Saitou \& Nei, 1987), and was evaluated by bootstrap sampling (Felsenstein, 1985). The following 16S rRNA/rDNA sequences were used for the phylogenetic analysis: Acidianus brierleyi DSM 1651 (X90477), Acidianus infernus DSM 3191 (X89852), Aeropyrum pernix K1 (D83259), Desulfurococcus mobilis (M36474), Metallosphaera sedula DSM 5348 (X90481), Pyrobaculum aerophilum im2 (L07510), Pyrobaculum islandicum geo3 (L07511), Pyrodictium occultum PL19 (M21087), 'Pyrolobus fumarii' 1A (X99555), Stetteria hydrogenophila 4ABC (Y07784), Sulfolobus acidocaldarius ATCC 33909 (D14876), Sulfolobus metallicus DSM 6482 (X90479), Sulfolobus shibatae DSM 5389 (M32504), Thermococcus celer DSM 2476 (M21529), Thermofilum pendens DSM 2475 (X14835) and Thermoproteus tenax (M35966).

\section{RESULTS}

\section{Isolation}

Seventeen samples of hot spring water, solfataric soils and muds were collected from nine different solfataric areas in Japan. The samples were inoculated in the enrichment medium at $70^{\circ} \mathrm{C}$ and $\mathrm{pH} 5.0$ under $\mathrm{H}_{2} /-$ $\mathrm{CO}_{2}(4: 1, \mathrm{v} / \mathrm{v} ; 100 \mathrm{kPa})$ gas mixture. After 1 week cultivation, regular or irregular coccoid cells prevailed in most of the cultures. However, rod-shaped cells were seen, accompanied by lesser numbers of coccoid cells, in enrichment cultures of the following three samples: mud from a spring pool, Noji-onsen, Fuku- shima; water from a flowing spring, Kawayu-onsen, Hokkaido; and water from a spring pool, Tamagawaonsen, Akita. The original temperatures of the first and last samples were 80 and $65^{\circ} \mathrm{C}$, respectively. The $\mathrm{pH}$ values of the three samples measured at room temperature were $2 \cdot 4,2 \cdot 0$ and $1 \cdot 8$, respectively. Initially, the serial dilution method (1:10 dilution) with the medium used for the enrichment failed to separate the rod-shaped cells from the coccoid cells. However, when the serial dilutions were repeated with the enrichment medium containing an archaeal cell-extract solution, the coccoid cells were eliminated in the growth culture at the highest dilution. Therefore, the enrichment medium containing the archaeal cellextract solution was used for the following isolation procedures, and each of the diluted cultures was incubated for 2 weeks. The serial dilutions $(1: 10$ dilution) were repeated twice; then, the growth culture at the highest dilution was again serially diluted $(1: 10)$, and each of the dilutions was further divided into five bottles and incubated. One of the cultures at the highest dilution was again serially diluted $(1: 10 \mathrm{di}-$ lution). The final growth cultures were assigned IC$125^{\mathrm{T}}$ (from Noji-onsen), IC-139 (from Kawayu-onsen) and IC-142 (from Tamagawa-onsen). The purity of the strains was confirmed by microscopic observations for the cultures grown under various growth conditions (e.g. temperature range of $37-85^{\circ} \mathrm{C}, \mathrm{pH}$ range of $2 \cdot 0-7 \cdot 5)$.

In addition to the three rod-shaped strains, coccoid strains were obtained from these three samples following enrichment under aerobic and/or acidic ( $\mathrm{pH} 2 \cdot 5)$ conditions, or under an $\mathrm{N}_{2}$ atmosphere $\left(70{ }^{\circ} \mathrm{C}, \mathrm{pH} 5 \cdot 0\right)$. Moreover, other rod-shaped strains were isolated from the samples of Noji-onsen and
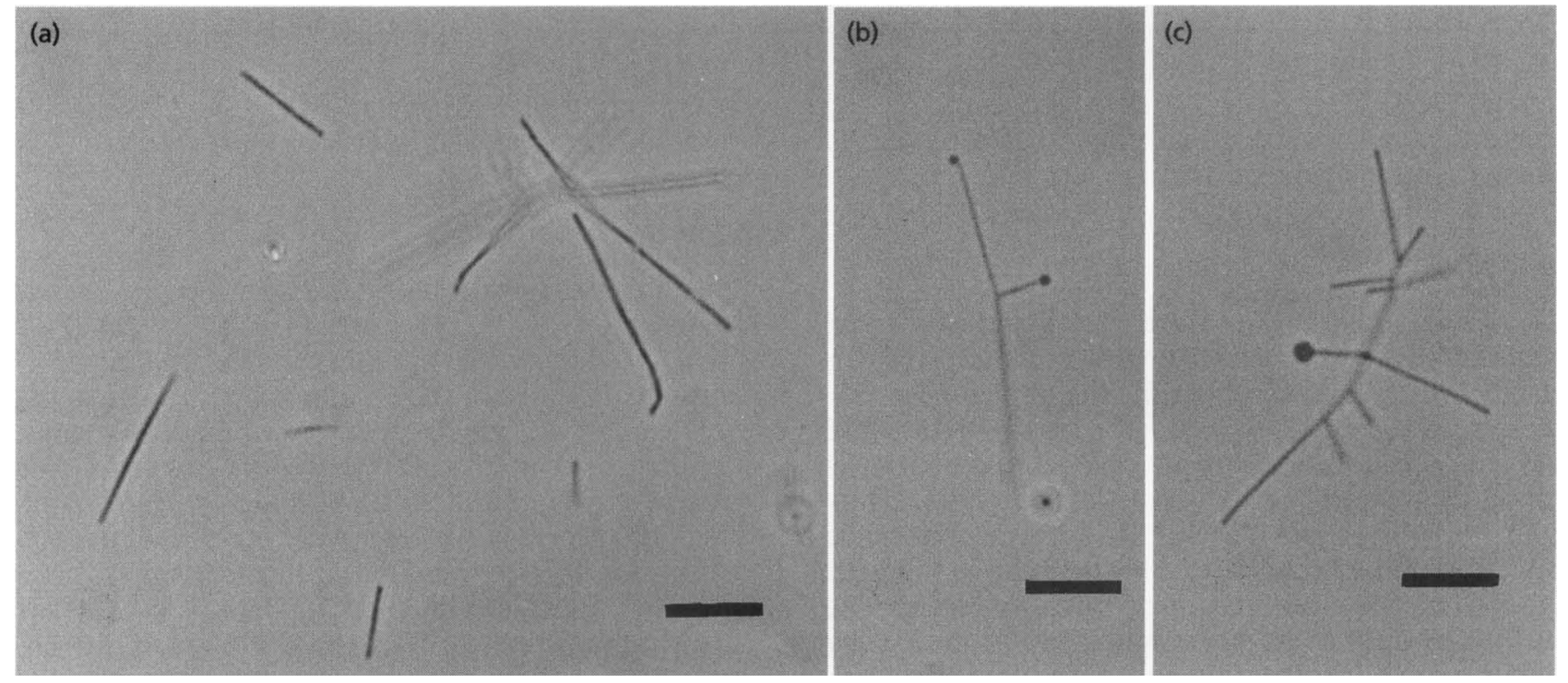

Fig. 1. Phase-contrast micrographs of the isolate $I C-125^{\top}$. Cells were rods (a) and occasionally branched out singly (b) or extensively (c). Some cells bore spherical bodies at the ends of the cells (b, c). Bars, $5 \mu \mathrm{m}$. 

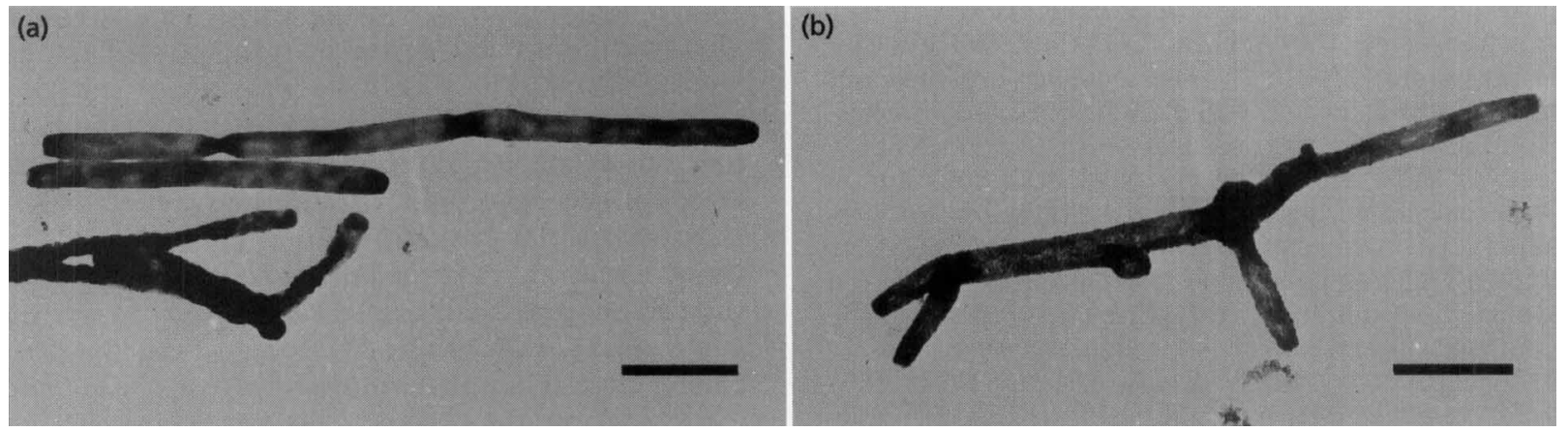

Fig. 2. Transmission electron micrographs of IC $-125^{\top}$ isolates. Cells seemed to multiply by constriction (a) or branching (b). Bars, $2 \mu \mathrm{m}$.

Table 1. Effect of the cell-extract and vitamin mixture on the growth of the isolate IC$125^{\top}$

The relative growth yield was determined by means of the protein content after 1 week of cultivation under $\mathrm{H}_{2} / \mathrm{CO}_{2}(4: 1, \mathrm{v} / \mathrm{v} ; 100 \mathrm{kPa})$ atmosphere. The yield of the culture with the cell-extract from Sulfolobus acidocaldarius JCM 9062 is expressed as $100 \%$ (corresponded to $171 \mu \mathrm{g}$ protein $\mathrm{ml}^{-1}$ ). The solutions of the cell-extracts and the vitamin mixture were added to the media at final concentrations of $1.0 \%(\mathrm{v} / \mathrm{v})$, respectively.

\begin{tabular}{|lc|}
\hline Additive & Relative growth yield (\%) \\
\hline None & $43 \cdot 0$ \\
Cell-extract from: & $100 \cdot 0$ \\
Sulfolobus acidocaldarius JCM 9062 & $86 \cdot 7$ \\
Methanosarcina barkeri JCM 10043 & $86 \cdot 3$ \\
Halobacterium salinarum JCM 8978 & $82 \cdot 1$ \\
Thermoplasma acidophilum JCM 9062 & $39 \cdot 3$ \\
Escherichia coli JCM 1649 & $84 \cdot 0$ \\
Vitamin mixture* & \\
\hline
\end{tabular}

* According to Balch et al. (1979).

Tamagawa-onsen with enrichment at $85^{\circ} \mathrm{C}$ and $\mathrm{pH} 5 \cdot 0$ under an $\mathrm{N}_{2}$ atmosphere (T. Itoh, K. Suzuki \& $\mathrm{T}$. Nakase, unpublished results).

\section{Morphology}

Cells of the three strains were mostly regular rods, straight or slightly curved with various length (Figs 1a and $2 \mathrm{a}$ ). Most cells were within the range $0.4-0.5 \times$ $5-20 \mu \mathrm{m}$. Frequently, long rods of up to $50 \mu \mathrm{m}$ were observed. In addition, bent cells, branched cells forming T-shapes or Y-shapes, and extensively branched cells existed (Fig. 1b, c; Fig. 2b). The proportion of the branching cells exceeded $20 \%$ of the total cells at the early stationary growth phase. The ends of the cells were rectangular to round. They sometimes had protruding spherical bodies, which measured $1-3 \mu \mathrm{m}$ in diameter, at the ends of the cells. Cells showing constriction were observed, as shown in Fig. 2(a), by transmission electron microscopy. This would imply that the cells divide by the constriction mode. Motility and flagella were not observed.

\section{Growth characteristics}

The three isolates proliferated under strictly anaerobic conditions with $\mathrm{N}_{2}, \mathrm{H}_{2} / \mathrm{CO}_{2}(4: 1, \mathrm{v} / \mathrm{v} ; 100 \mathrm{kPa})$ or $\mathrm{N}_{2} / \mathrm{CO}_{2}(4: 1, \mathrm{v} / \mathrm{v} ; 100 \mathrm{kPa})$ in the gas phase. To estimate the effect of the gas phase on the growth of the isolates, growth yields were determined by means of the protein contents after 1 week cultivation. When growth yields of the cultures under a $\mathrm{H}_{2} / \mathrm{CO}_{2}(4: 1$, $\mathrm{v} / \mathrm{v} ; 100 \mathrm{kPa})$ gas phase were regarded as $100 \%$ (corresponding to 163-204 $\mu \mathrm{g}$ protein $\mathrm{ml}^{-1}$ ), growth yields of the cultures under $\mathrm{N}_{2} / \mathrm{CO}_{2}(4: 1, \mathrm{v} / \mathrm{v} ; 100 \mathrm{kPa})$ and $\mathrm{N}_{2}$ gas phases were $88-109 \%$ and $60-66 \%$, respectively. Thus, the presence of $\mathrm{CO}_{2}$ in the gas phase enhanced growth to some extent. Sulfide was detected following growth. Under a gas phase of $5 \%$ air, growth occurred while the medium was oxidized 


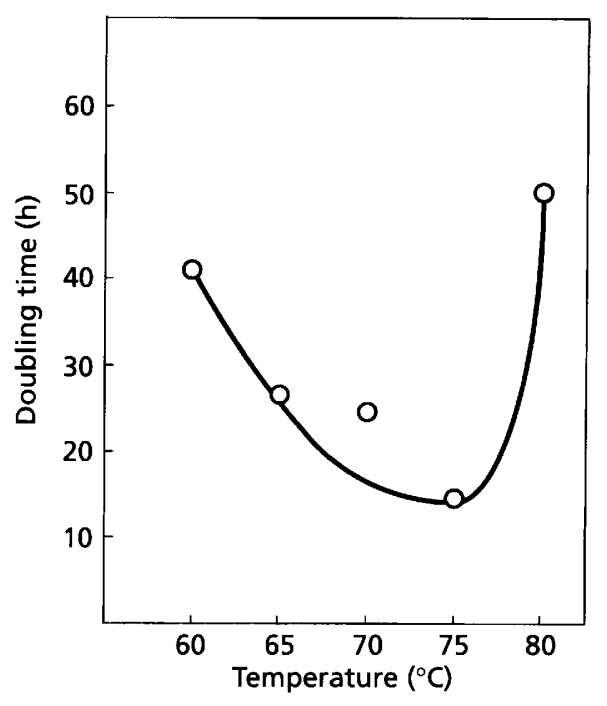

Fig. 3. Effect of temperature on the growth of isolate IC-125'. Strain $\mathrm{IC}-125^{\top}$ was grown in TCD medium at $\mathrm{pH} 4 \cdot 2$ under a $\mathrm{H}_{2} / \mathrm{CO}_{2} \quad(4: 1, \mathrm{v} / \mathrm{v} ; 100 \mathrm{kPa})$ atmosphere. Trisodium citrate $(10 \mathrm{mM})$ was added as a buffer agent. Growth rates were calculated from 4-5 points on the logarithmic part of the growth curve.

(as judged by the colour of resazurin). The growth yields of the microaerobic cultures were the same or less than those of the cultures with an $\mathrm{N}_{2}$ gas phase. No growth was observed if the gas phase was air. All of the archaeal cell-extract solutions examined, as well as a vitamin mixture solution of Balch et al. (1979) (final concn $1 \cdot 0 \%, \mathrm{v} / \mathrm{v}$ ), enhanced growth of strain IC- $125^{\mathrm{T}}$; however, the extract of $E$. coli JCM $1649^{\mathrm{T}}$ did not enhance growth, as shown in Table 1. The archaeal cell-extract solution or the vitamin mixture solution did not replace yeast extract as the carbon source (data not shown). None of the isolates grew autotrophically, in the absence of a carbon source, under a $\mathrm{H}_{2} / \mathrm{CO}_{2}$ $(4: 1, \mathrm{v} / \mathrm{v} ; 100 \mathrm{kPa})$ or a $\mathrm{N}_{2} / \mathrm{CO}_{2}(4: 1, \mathrm{v} / \mathrm{v} ; 100 \mathrm{kPa})$ atmosphere. They grew at $45-80^{\circ} \mathrm{C}$ under an $\mathrm{N}_{2}$ atmosphere. Under $\mathrm{a}_{2} / \mathrm{CO}_{2}$ atmosphere, they grew up to $82^{\circ} \mathrm{C}$, but failed to grow at $84^{\circ} \mathrm{C}$. When strain IC- $125^{\mathrm{T}}$ was cultivated at various temperatures $(60$, $65,70,75$ and $80^{\circ} \mathrm{C}$ ), optimal growth was observed at $75^{\circ} \mathrm{C}$ as shown in Fig. 3. The effect of $\mathrm{pH}$ on the growth was examined with either $10 \mathrm{mM}$ trisodium citrate (pH 2.0-5.5) or $10 \mathrm{mM}$ MES (pH 5.0-7.0) as buffer agents. In the absence of these buffer agents, the $\mathrm{pH}$ of the cultures, which was initially adjusted to $\mathrm{pH} 4 \cdot 0$, increased up to $5 \cdot 2-5 \cdot 3$ following growth. In the presence of $10 \mathrm{mM}$ trisodium citrate, strains IC$125^{\mathrm{T}}$ and IC-142 grew in a $\mathrm{pH}$ range of $3 \cdot 0-5 \cdot 1$, and strain IC-139 grew in a $\mathrm{pH}$ range of $2 \cdot 6-5 \cdot 1$. No strains grew at $\mathrm{pH} 1.9$ or 5.6 . In the media buffered with $10 \mathrm{mM}$ MES, all of the isolates grew at $\mathrm{pH}$ up to 5.9 , but not at $\mathrm{pH} 6 \cdot 1$. When strain IC- $125^{\mathrm{T}}$ was cultivated at various $\mathrm{pH}(3 \cdot 0,3 \cdot 7,4 \cdot 2,4 \cdot 7$ and $5 \cdot 0)$ with $10 \mathrm{mM}$ trisodium citrate, optimal growth was observed at

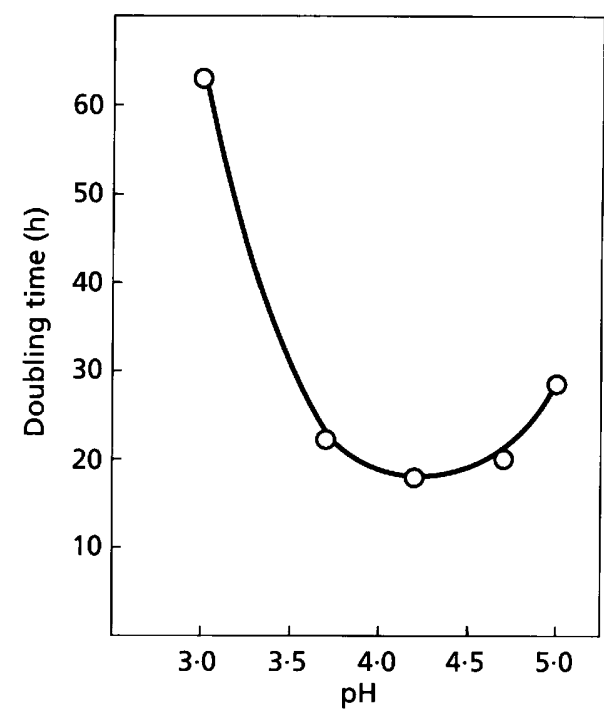

Fig. 4. Effect of $\mathrm{pH}$ on the growth of isolate $\mathrm{IC}-125^{\top}$. Strain IC$125^{\top}$ was grown in TCD medium at $75^{\circ} \mathrm{C}$ under a $\mathrm{H}_{2} / \mathrm{CO}_{2}(4: 1$, $\mathrm{v} / \mathrm{v} ; 100 \mathrm{kPa}$ ) atmosphere. The buffer was $10 \mathrm{mM}$ trisodium citrate. Growth rates were calculated from 3-6 points on the logarithmic part of the growth curves.

$\mathrm{pH} 4 \cdot 2$, as shown in Fig. 4. Under optimal growth conditions $\left[75^{\circ} \mathrm{C}, \mathrm{pH} 4.2\right.$ under $\mathrm{H}_{2} / \mathrm{CO}_{2}(4: 1, \mathrm{v} / \mathrm{v}$; $100 \mathrm{kPa}$ )], strain IC-125 $5^{\mathrm{T}}$ grew with a doubling time of 15-18 $\mathrm{h}$. The stationary cultures contained $200-230 \mu \mathrm{g}$ protein $\mathrm{ml}^{-1}$ and $3-4 \times 10^{7}$ cells $\mathrm{ml}^{-1}$. The three isolates grew in the medium containing $1.0 \%(\mathrm{w} / \mathrm{v}) \mathrm{NaCl}$, but not in $1.5 \%(\mathrm{w} / \mathrm{v}) \mathrm{NaCl}$.

\section{Utilization of carbon sources}

Of the carbon sources tested, the three strains grew well in the presence of yeast extract and gelatin. Glycogen, starch, beef extract, casamino acids, malt extract, peptone and tryptone supported moderate growth. No or negligible growth was obtained on any of the mono- and disaccharides, organic acids, alcohols, amide and amines studied so far. When strain IC$125^{\mathrm{T}}$ was grown under a $\mathrm{H}_{2} / \mathrm{CO}_{2}(4: 1, \mathrm{v} / \mathrm{v} ; 100 \mathrm{kPa})$ atmosphere, a similar utilization pattern was obtained. Yeast extract was added as a carbon source at various concentrations $(0.02,0.05,0.1,0.2,0.5$ and $1.0 \%$, $\mathrm{w} / \mathrm{v})$; the three strains grew at concentrations up to $0.5 \%$, but not at $1.0 \%$. The highest growth yields were obtained with $0 \cdot 2 \%$ yeast extract, but the growth was slower than in cultures grown with $0.1 \%$ yeast extract (data not shown).

\section{Possible electron acceptors}

The three stains showed no or negligible growth on the basal medium without an electron acceptor. Addition of sulfur, thiosulfate or L-cystine supported growth, and sulfate supported scanty growth. When strain IC$125^{\mathrm{T}}$ was grown under a $\mathrm{H}_{2} / \mathrm{CO}_{2}(4: 1, \mathrm{v} / \mathrm{v} ; 100 \mathrm{kPa})$ 
Table 2. Levels of DNA relatedness between isolates and Thermoproteus tenax JCM $9277^{\top}$

\begin{tabular}{|lcrrr|}
\hline \multirow{2}{*}{ Strain } & \multicolumn{4}{c|}{ Relatedness (\%) with biotinylated DNA from: } \\
\cline { 2 - 5 } & IC-125 $^{\mathbf{T}}$ & IC-139 & IC-142 & JCM 9277 $^{\mathbf{T}}$ \\
\hline Isolate IC-125 & 100 & 79 & 81 & 2 \\
Isolate IC-139 & 79 & 100 & 79 & 2 \\
Isolate IC-142 & 90 & 87 & 100 & 1 \\
Thermoproteus tenax JCM $9277^{\mathrm{T}}$ & 2 & 2 & 2 & 100 \\
\hline
\end{tabular}

atmosphere, slight growth occurred in the presence of nitrate or $\mathrm{FeCl}_{3}$.

\section{Antibiotic sensitivity}

The isolates were insensitive to chloramphenicol, oleandomycin and kanamycin. Even though the antimicrobial activity of rifampicin was drastically reduced after $3 \mathrm{~d}$ in the medium, the isolates did not grow even after 2 weeks. No antimicrobial activity of vancomycin, ampicillin and erythromycin remained after $3 \mathrm{~d}$; these antibiotics had no effect on the growth of the isolates.

\section{Lipid analysis}

The three isolates contained large amounts of tetraether core lipids and small amounts of diether core lipids. No fatty acid was found. On the thin-layer chromatogram developed with hexane/diethylether $(70: 30, \mathrm{v} / \mathrm{v})$, there were at least five spots which corresponded to glycerol-bisdiphytanyl-glycerol tetraethers. All of these lipids are considered to be different cyclized variations in the isopranoid chains.

\section{$\mathbf{G}+\mathbf{C}$ contents of DNAs}

The $\mathrm{G}+\mathrm{C}$ contents of DNAs from the strains $\mathrm{IC}-125^{\mathrm{T}}$, IC- 139 and IC-142 were $52 \cdot 4,51.9$ and $52.4 \mathrm{~mol} \%$, respectively.

\section{DNA-DNA hybridization}

Values for DNA-DNA hybridization between the three isolates and Thermoproteus tenax $\mathrm{JCM} 9277^{\mathrm{T}}$ are shown in Table 2 . The three isolates IC- $125^{\mathrm{T}}$, IC-139 and IC-142 showed high levels of hybridization values $(>79 \%)$ to each other.

\section{5 rDNA analysis}

For the $16 \mathrm{~S}$ rDNA of strain IC- $125^{\mathrm{T}}$, the sequence of 1469 positions was determined. The $\mathrm{G}+\mathrm{C}$ content of the rDNA was $63.9 \mathrm{~mol} \%$. The sequence was aligned with those of other crenarchaeotes and Thermococcus celer. All of the small subunit rRNA sequence signatures defining the crenarchaeotes (Winker \& Woese, 1991), except for that at positions 1244:1293, were

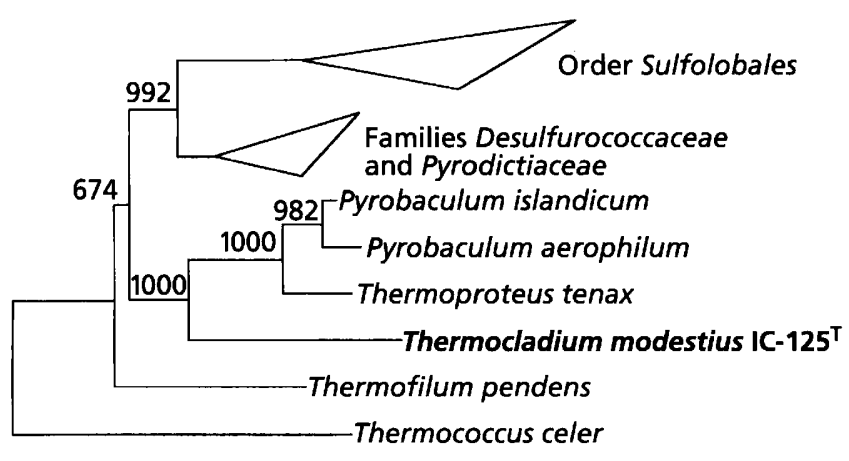

$2.0 \%$

Fig. 5. Phylogenetic tree showing the position of Thermocladium modestius strain IC-125 $5^{\top}$. The tree is constructed by the neighbour-joining method derived from the 165 rRNA/rDNA sequences. The numbers indicate the bootstrap scores of 1000 trials. The bar represents $2 \%$ nucleotide substitution. Accession numbers of nucleotide sequences cited are: Pyrobaculum aerophilum im2 (L07510); Pyrobaculum islandicum geo3 (L07511); Thermococcus celer DSM 2476 (M21529); Thermofilum pendens DSM 2475 (X14835); and Thermoproteus tenax (M35966). The clade of the order Sulfolobales comprises: Acidianus brierleyi DSM 1651 (X90477); Acidianus infernus DSM 3191 (X89852); Metallosphaera sedula DSM 5348 (X90481); Sulfolobus acidocaldarius ATCC 33909 (D14876); Sulfolobus metallicus DSM 6482 (X90479); and Sulfolobus shibatae DSM 5389 (M32504). The clade of the families Desulfurococcaceae and Pyrodictiaceae comprises: Aeropyrum pernix K1 (D83259); Desulfurococcus mobilis (M36474); Pyrodictium occultum PL19 (M21087); 'Pyrolobus fumarii' '1A (X99555); and Stetteria hydrogenophila 4ABC (Y07784).

found in the sequence from strain IC- $125^{\mathrm{T}}$. The base pair at positions $1244: 1293$ in $\mathrm{IC}-125^{\mathrm{T}}$ were $\mathrm{T}: \mathrm{A}$, whereas those of the other crenarchaeotes are $R$ $(\mathrm{A} / \mathrm{G}): \mathrm{Y}(\mathrm{T} / \mathrm{C})$. To calculate the similarities between strain IC- $125^{\mathrm{T}}$ and the other crenarchaeotes, 1213 bases of each sequence were compared. The $\mathrm{G}+\mathrm{C}$ contents of the sequences compared were $59 \cdot 2$ $67.5 \mathrm{~mol} \%$. The phylogenetic tree derived from the 16S rRNA/rDNA sequences is shown in Fig. 5. Strain IC- $125^{\mathrm{T}}$ clustered with members of the family Thermoproteaceae. This cluster is supported by a high bootstrap value $(100 \%)$. Strain IC- $125^{\mathrm{T}}$ formed a separate lineage in this cluster, and the similarity values between strain IC- $125^{\mathrm{T}}$ and the species of Thermoproteus and 
Pyrobaculum were in the range $90 \cdot 6-90.9 \%$. The representative species of another family Thermofilaceae, Thermofilum pendens, was branched outside the family Thermoproteaceae; however, bootstrap sampling gave only $67 \%$ confidence in this position. The transversion analysis (Woese et al., 1991) did not affect the branching patterns, except for a small change in the position of Sulfolobus metallicus (tree not shown). The partial sequences of strains IC-139 (positions 401-657 in the $E$. coli system) and IC-142 (positions 363-657) were identical with that of strain IC- $125^{\mathrm{T}}$.

\section{DISCUSSION}

The three extremely thermophilic, rod-shaped isolates, IC- $125^{\mathrm{T}}$, IC-139 and IC-142, were obtained from samples taken from the acidic hot spring areas in Japan. These samples were considered to house a variety of thermophilic micro-organisms, and enrichment under several growth conditions in regard to temperature, $\mathrm{pH}$ and gas phase enabled isolation of different types of strains. The three rod-shaped strains were enriched in medium at $70{ }^{\circ} \mathrm{C}$ and $\mathrm{pH} 5.0$ under a $\mathrm{H}_{2} / \mathrm{CO}_{2}(4: 1, \mathrm{v} / \mathrm{v} ; 100 \mathrm{kPa})$ atmosphere, and they grew optimally around $75^{\circ} \mathrm{C}$ and $\mathrm{pH} 4 \cdot 0$. Although the three strains grew under an $\mathrm{N}_{2}$ atmosphere, the enrichment of the samples under an $\mathrm{N}_{2}$ atmosphere $\left(70^{\circ} \mathrm{C}, \mathrm{pH} 5.0\right)$ resulted in coccoid isolates. The temperatures of the original samples were adequate for the strains to grow (i.e. $65-80^{\circ} \mathrm{C}$ ). In contrast, the $\mathrm{pH}$ values of these sources were lower than their growth $\mathrm{pH}$ ranges. They may extend their growth $\mathrm{pH}$ ranges in the sampling sites, or they may be allochthonous organisms.

The presence of ether lipids and absence of fatty acids support the conclusion that the three isolates belong to the domain Archaea. In addition, the 16S rDNA sequences of the isolates indicated that they were crenarchaeotes. Rod-shaped crenarchaeotes are currently included in the order Thermoproteales, which has been revised recently on the grounds of $16 \mathrm{~S}$ rRNA/rDNA sequence similarities (Bruggraf et al., 1997). Two families, Thermofilaceae and Thermoproteaceae, are known in this order. The former family contains only the genus Thermofilum (Zillig et al., 1983), whereas the latter family comprises two genera, Pyrobaculum (Huber et al., 1987; Völkl et al., 1993) and Thermoproteus (Bonch-Osmolovskaya et al., 1990; Zillig, 1989; Zillig et al., 1981). Both genera are commonly encountered in continental solfataric areas, although Pyrobaculum aerophilum was isolated from a boiling marine waterhole (Völkl et al., 1993). The two families are also differentiated by cell thickness (i.e. the cell widths of members of the family Thermofilaceae are less than $0.35 \mu \mathrm{m}$, while those of members of the family Thermoproteaceae are at least $0.4 \mu \mathrm{m})$. The distinctive rod shape and the cell widths $(0.4-0.5 \mu \mathrm{m})$ of our isolates are also consistent with their placement within the family Thermoproteaceae.

The morphology of the three isolates is similar to that found within the genera Thermoproteus and Pyrobaculum. The isolates formed regular rods measuring $0.4-0.5 \mu \mathrm{m}$ in width; cells were bent, branched, or had terminal spheres which sometimes looked like 'golf clubs'. These morphological features are common to the two genera Thermoproteus and Pyrobaculum (Huber et al., 1987; Völkl et al., 1993; Zillig, 1989; Zillig et al., 1981). The new isolates, however, tended to form extensively branched cells more frequently than the strains of these genera. Unlike Pyrobaculum species, the isolates had neither flagella nor motility. Branching, budding and cell constriction would be common cell-multiplication modes for the order Thermoproteales.

Although the three isolates favoured strictly anaerobic growth, they grew under low amounts of air. Except for Pyrobaculum aerophilum, all of the Thermoproteaceae species are strict anaerobes and do not grow microaerobically. Pyrobaculum aerophilum grows under a low concentration of $\mathrm{O}_{2}(<5 \%)$, and uses $\mathrm{O}_{2}$ as an electron acceptor (Völkl et al., 1993). Although our isolates tolerated $5 \%(\mathrm{v} / \mathrm{v})$ air in the gas phase, it is unlikely that $\mathrm{O}_{2}$ was an electron acceptor because it did not increase growth yields. The archaeal cellextract solution stimulates growth of the new isolates. This preparation seems to be related to the growth factor required for Thermofilum pendens (Zillig et al., 1983). Unlike Thermofilum pendens, growth of the isolates is enhanced by the cell-extract solution from Thermoplasma or by a vitamin mixture (Balch et al., 1979). At the moment, therefore, it is not clear whether or not the actual elements contributing to the growth enhancement of our isolates and Thermofilum pendens are identical. The growth temperature ranges of the isolates were significantly lower than those of other members of the order Thermoproteales, which grow optimally at hyperthermophilic ranges (i.e. $85-100{ }^{\circ} \mathrm{C}$ ). The three isolates grew optimally at $75^{\circ} \mathrm{C}$; thus, they are the first examples of non-hyperthermophilic strains among the rod-shaped crenarchaeotes. Furthermore, the optimal growth $\mathrm{pH}$ was lower than that of the three described genera. The three isolates were insensitive to chloramphenicol, kanamycin and oleandomycin; however, they were sensitive to rifampicin, like strains of the genus Pyrobaculum (Huber et al., 1987; Völkl et al., 1993).

The $\mathrm{G}+\mathrm{C}$ contents of DNAs of the three isolates are $52 \mathrm{~mol} \%$ and clearly different from those of Thermoproteus species (Bonch-Osmolovskaya et al., 1990; Zillig et al., 1981; T. Itoh, K. Suzuki \& T. Nakase, unpublished results) and Thermofilum pendens (Zillig et al., 1983) which are in the range $56-60 \mathrm{~mol} \%$. Although the $\mathrm{G}+\mathrm{C}$ contents of Pyrobaculum species are reported to be $44-52 \mathrm{~mol} \%$ (Huber et al., 1987; Völkl et al., 1993), the values for the type strains of the three species were estimated in our laboratory to be about $50 \mathrm{~mol} \%$ (T. Itoh, K. Suzuki \& T. Nakase, unpublished results). The $16 \mathrm{~S}$ rDNA analysis showed that strain IC- $125^{\mathrm{T}}$ clustered with the members of the family Thermoproteaceae. This cluster is supported by 
a high bootstrap value $(100 \%)$, and strain $\mathrm{IC}-125^{\mathrm{T}}$ apparently belongs in an independent lineage within the cluster. Accordingly, in line with the phenotypic differences, particularly those of the growth temperature, growth $\mathrm{pH}$ and the $\mathrm{G}+\mathrm{C}$ contents of genomic DNAs, the three strains should be recognized as a new genus in the family Thermoproteaceae. The three isolates belong to one species because of the phenotypic similarities described above and high levels of DNA-DNA relatedness.

On the basis of our results, the name Thermocladium modestius gen. nov., sp. nov. is proposed for the three isolates. The type strain of the new species is IC $-125^{\mathrm{T}}$. The three strains IC-125 $5^{\mathrm{T}}$ IC-139 and IC-142 have been deposited in the Japan Collection of Microorganisms, The Institute of Physical and Chemical Research (RIKEN), Saitama, Japan, with accession numbers JCM $10088^{\mathrm{T}}$, JCM 10089 and JCM 10090, respectively.

\section{Description of Thermocladium gen. nov.}

Thermocladium (Ther.mo.cla'di.um. Gr. adj. thermus hot; Gr. dim. n. cladion small branch; M.L. neut. n. Thermocladium a hot small twig, indicating branching cells in a hot environment).

Cells are straight or slightly curved rods, and sometimes bend and branch out singly or extensively. Most cells are $0.4-0.5 \times 5-20 \mu \mathrm{m}$. Spherical bodies may protrude at the ends of the cells. Cells multiply by branching and budding and divide by the constriction mode. No flagella or motility are observed. Grows anaerobically or microaerobically. Prefers extremely thermophilic and weakly acidic conditions to grow (e.g. $70-75^{\circ} \mathrm{C}, \mathrm{pH} 4 \cdot 0-4 \cdot 5$ ). Insensitive to chloramphenicol, kanamycin and oleandomycin, but sensitive to rifampicin.

Possesses several (at least five) tetraether core lipids containing cyclopentane rings in the isopranyl chains. The $\mathrm{G}+\mathrm{C}$ content of genomic DNA is $52 \mathrm{~mol} \%$. The $16 \mathrm{~S} \mathrm{rDNA}$ is typical of a crenarchaeote in the sequence signature analysis, except for base pair positions 1244:1293. Phylogenetically, falls under an independent lineage in the family Thermoproteaceae. Inhabits acidic, extremely thermophilic (i.e. $65-80^{\circ} \mathrm{C}$ ), terrestrial hot spring area. Monospecific, at present. The type species is Thermocladium modestius.

\section{Description of Thermocladium modestius sp. nov.}

Thermocladium modestius [mo.des'ti.us. L. comp. adj. modestior (neut. modestius) modester, referring to the growth temperature range].

Cells are rod-shaped. Grows anaerobically or microaerobically. Heterotrophic. Growth is stimulated by $\mathrm{CO}_{2}$ in the gas phase and by archaeal cell-extract or a vitamin mixture. Growth occurs at $45-82{ }^{\circ} \mathrm{C}$ and is optimal around $75^{\circ} \mathrm{C}$. Growth occurs at $\mathrm{pH} 2 \cdot 6-5 \cdot 1$ and is optimal at $\mathrm{pH} 4.0$ when buffered with $10 \mathrm{mM}$ trisodium citrate. Growth $\mathrm{pH}$ is extended to $\mathrm{pH} 5.9$ when buffered with $10 \mathrm{mM}$ MES. Under optimal conditions $\left[75^{\circ} \mathrm{C}, \mathrm{pH} 4 \cdot 2\right.$, under $\mathrm{H}_{2} / \mathrm{CO}_{2}(4: 1$, v/v; $100 \mathrm{kPa}$ ) gas mixture], strain IC-125 $5^{\mathrm{T}}$ grows with a doubling time of $15-18 \mathrm{~h}$. Grows at low salinity $(0-1.0 \% \mathrm{NaCl})$. Utilizes glycogen, starch, beef extract, casamino acids, peptone, malt extract, tryptone and yeast extract as carbon sources. Grows best with $0 \cdot 1-0.2 \%$ yeast extract, but does not grow with $1.0 \%$ yeast extract. Requires sulfur, thiosulfate, L-cystine or sulfate as electron acceptors. With $\mathrm{H}_{2} / \mathrm{CO}_{2}(4: 1, \mathrm{v} / \mathrm{v}$; $100 \mathrm{kPa}$ ) as gas phase, may utilize nitrate or $\mathrm{FeCl}_{3}$ as electron acceptors. Produces sulfide during growth. The $\mathrm{G}+\mathrm{C}$ content of genomic DNA is $52 \mathrm{~mol} \%$. The type strain, IC- $125^{\mathrm{T}}\left(=\mathrm{JCM} 10088^{\mathrm{T}}\right)$, was isolated from solfataric mud at Noji-onsen, Fukushima, Japan. Two additional strains, IC-139 (= JCM 10089) and IC-142 (= JCM 10090), are also included in this species.

\section{REFERENCES}

Balch, W. E., Fox, G. E., Magrum, L. J., Woese, C. R. \& Wolfe, R. S. (1979). Methanogens: re-evaluation of a unique biological group. Microbiol Rev 43, 260-296.

Barns, S. M., Fundyga, R. E., Jeffries, M. W. \& Pace, N. R. (1994). Remarkable archaeal diversity detected in a Yellowstone National Park hot spring environment. Proc Natl Acad Sci USA 91, 1609-1613.

Bonch-Osmolovskaya, E. A., Miroshnichenko, M. L., Kostrikina, N. A., Chernych, N. A. \& Zavarzin, G. A. (1990). Thermoproteus uzoniensis sp. nov., a new extremely thermophilic archaebacterium from Kamchatka continental hot springs. Arch Microbiol 154, 556-559.

Brock, T. D., Brock, K. M., Belly, R. T. \& Weiss, R. L. (1972). Sulfolobus: a new genus of sulfur-oxidizing bacteria living at low pH and high temperature. Arch Microbiol 84, 54-68.

Bruggraf, S., Huber, H. \& Stetter, K. O. (1997). Reclassification of the crenarchaeal orders and families in accordance with $16 \mathrm{~S}$ rRNA sequence data. Int $J$ Syst Bacteriol 47, 657-660.

Ezaki, T., Hashimoto, Y. \& Yabuuchi, E. (1989). Fluorometric deoxyribonucleic acid-deoxyribonucleic acid hybridization in microdilution wells as an alternative to membrane filter hybridization in which radioisotopes are used to determine genetic relatedness among bacterial strains. Int J Syst Bacteriol 39, 224-229.

Felsenstein, J. (1985). Confidence limits on phylogenies: an approach using the bootstrap. Evolution 39, 783-791.

Fiala, G., Stetter, K. O., Jannasch, H. W., Langworthy, T. A. \& Madon, J. (1986). Staphylothermus marinus sp. nov. represents a novel genus of extremely thermophilic submarine heterotrophic archaebacteria growing up to $98^{\circ} \mathrm{C}$. Syst Appl Microbiol 8, 106-113.

Hershberger, K. L., Barns, S. M., Reysenbach, A. L., Dawson, S. C. $\&$ Pace, N. R. (1996). Wide diversity of Crenarchaeota. Nature 384,420 .

Huber, R. \& Stetter, K. O. (1992). The order Thermoproteales. In The Prokaryotes, 2nd edn, pp. 677-683. Edited by A. Balows, H. G. Trüper, M. Dworkin, W. Harder \& K.-H. Schleifer. New York: Springer.

Huber, R., Langworthy, T. A., König, H., Thomm, M., Woese, C. R., Sleytr, U. B. \& Stetter, K. O. (1986). Thermotoga maritima sp. 
nov. represents a new genus of unique extremely thermophilic eubacteria growing up to $90^{\circ} \mathrm{C}$. Arch Microbiol 144, 324-333.

Huber, R., Kristjansson, J. K. \& Stetter, K. O. (1987). Pyrobaculum gen. nov., a new genus of neutrophilic, rod-shaped archaebacteria from continental solfataras growing optimally at $100{ }^{\circ} \mathrm{C}$. Arch Microbiol 149, 95-101.

Ross, H. N. M., Grant, W. D. \& Harris, J. E. (1985). Lipids in archaebacterial taxonomy. In Chemical Methods in Bacterial Systematics, pp. 289-300. Edited by M. Goodfellow \& D. E. Minnikin. London: Academic Press.

Saitou, N. \& Nei, M. (1987). The neighbor-joining method: a new method for reconstructing phylogenetic trees. Mol Biol Evol 4, 406-425.

Segerer, A. H. \& Stetter, K. O. (1992). The order Sulfolobales. In The Prokaryotes, 2 nd edn, pp. 684-701. Edited by A. Balows, H. G. Trüper, M. Dworkin, W. Harder \& K. H. Schleifer. New York: Springer.

Stetter, K. O. (1996). Hyperthermophilic procaryotes. FEMS Microbiol Rev 18, 149-158.

Tamaoka, J. (1994). Determination of DNA base composition. In Chemical Methods in Prokaryotic Systematics, pp. 463-470. Edited by M. Goodfellow \& A. G. O'Donnell. Chichester: Wiley.

Thompson, J. D., Higgins, D. G. \& Gibson, T. J. (1994). CLUSTAL $\mathrm{W}$ : improving the sensitivity of progressive multiple sequence alignment through sequence weighting, position-specific gap penalties and weight matrix choice. Nucleic Acids Res 22, $4673-4680$.

Trincon, A., de Rosa, M., Gambacorta, A., Lanzotti, V., Nicolaus, B., Harris, J. E. \& Grant, W. D. (1988). A simple chromatographic procedure for the detection of cyclized archaebacterial glycerolbisdiphytanyl-glycerol tetraether core lipids. J Gen Microbiol 134, 3159-3163.
Völkl, P., Huber, R., Drobner, E., Rachel, R., Burggraf, S., Trincone, A. \& Stetter, K. O. (1993). Pyrobaculum aerophilum sp. nov., a novel nitrate-reducing hyperthermophilic archaeum. Appl Environ Microbiol 59, 2918-2926.

Winker, S. \& Woese, C. R. (1991). A definition of the domains Archaea, Bacteria and Eucarya in terms of small subunit ribosomal RNA characteristics. Syst Appl Microbiol 14, 305-310.

Woese, C. R., Kandler, O. \& Wheelis, M. L. (1990). Towards a natural system of organisms: proposal for the domains Archaea, Bacteria, and Eucarya. Proc Natl Acad Sci USA 87, 4576 4579.

Woese, C. R., Achenbach, L., Rouviere, P. \& Mandelco, L. (1991). Archaeal phylogeny: reexamination of the phylogenetic position of Archaeoglobus fulgidus in light of certain compositioninduced artifacts. Syst Appl Microbiol 14, 364-371.

Zehnder, A. J. B. \& Wuhrmann, K. (1976). Titanium (III) citrate à a nontoxic oxidation-reduction buffering system for the culture of obligate anaerobes. Science 194, 1165-1166.

Zeikus, J. G. (1977). The biology of methanogenic bacteria. Bacteriol Rev 41, 514-541.

Zillig, W. (1989). Genus I. Thermoproteus Zillig and Stetter 1982, $267^{\mathrm{VP}}$. In Bergey's Manual of Systematic Bacteriology, vol. 3, pp. 2241 . Edited by J. T. Staley, M. P. Bryant, N. Pfennig \& J. G. Holt. Baltimore: Williams \& Wilkins.

Zillig, W., Stetter, K. O., Schäfer, W., Janekovic, D., Wunderl, S., Holz, I. \& Palm, P. (1981). Thermoproteales: a novel type of extremely thermoacidophilic anaerobic archaebacteria isolated from Icelandic solfataras. Zentbl Bakteriol Mikrobiol Hyg $1 \mathrm{Abt}$ Orig C 2, 205-227.

Zillig, W., Gierl, A., Schreiber, G., Wunderl, S., Janekovic, D., Stetter, K. O. \& Klenk, H. P. (1983). The archaebacterium Thermofilum pendens represents, a novel genus of the thermophilic, anaerobic sulfur respiring Thermoproteales. Syst Appl Microbiol 4, 79-87. 